\title{
Priestly Courses and the Administration of Time in Neo-Babylonian Temples
}

\author{
Caroline Waerzeggers \\ Leiden University
}

\section{Introduction}

Rotation was an important principle of organization of priestly labor in Jerusalem's Second Temple. The rota of twenty-four families, who each served one week in a fixed order, was such a powerful source of identity that it persisted in Jewish society and culture long after the temple itself ceased to function. The importance of this institution is also reflected in the stories that were told about its origins. According to the Book of Chronicles, it was King David who created the twenty-four courses of priests and Levites, whereas the community at Qumran placed the first turn of the mishmarot at creation itself. ${ }^{1}$ In light of their importance for temple and society, the priestly watches have received due attention in scholarship. Historically, it is believed that the twenty-four divisions were created, not under King David, but in the Second Temple period. ${ }^{2}$ Whether the institution had earlier historical origins is unknown. Evidence of rotating temple offices in Egypt since the Old Kingdom (the phylai, as these

1 On David and the priestly divisions in Chronicles, see Simon J. De Vries, "Moses and David as Cult Founders in Chronicles," JBL 107 (1988): 619-39; Hugh G.M. Williamson, "The Origins of the Twenty-Four Priestly Courses: A Study of 1 Chronicles xxiii-xxvii," in Studies in the Historical Books of the Old Testament, ed. J.A. Emerton, VTSup 30 (Leiden: Brill, 1979), 25168. For Qumran, see Sacha Stern, "Qumran Calendars and Sectarianism," in The Oxford Handbook of the Dead Sea Scrolls, ed. J.J. Colins and T.H. Lim (Oxford: Oxford University Press, 2010), 232-53. For the Talmudic traditions and epigraphic materials from late antique synagogues, see Jacob Liver and Daniel Sperber, "Mishmarot and Ma'amadot," EncJud, 2d ed., 14:317-19; Martha Himmelfarb, A Kingdom of Priests: Ancestry and Merit in Ancient Judaism (Philadelphia: University of Pennsylvania Press, 2006), 171-73.

2 The historical origin of the twenty-four divisions is disputed, with, for example, Williamson ("Origins") arguing for a date in the late Persian period and Joachim Schaper, Priester und Leviten im achämenidischen Juda: Studien zur Kult- und Sozialgeschichte Israels in persischer Zeit, FAT 31 (Tübingen: Mohr Siebeck, 2000), 222-25 for an early post-exilic date. 
Egyptian courses would become known in the Greco-Roman period) is often cited as a possible model from the pre-exilic Near East. ${ }^{3}$

In this paper, I want to draw attention to rotational service in Babylonian temples of the 7 th and 6 th centuries BCE. The cyclical system of temple service is comparable to the mishmarot and mahlaqot of the biblical and extra-biblical texts, both in its general operation and in certain details. We find rotas of twenty-four service slots (among other rhythms), 7-day shifts, the involvement of batey avot or father's houses, the persistence of ancestral rights on labor slots across generations, and possibly the casting of lots. But there are also differences. In Judea, the mishmarot achieved far greater significance in society than the priestly watches in Babylonia, as far as we know. The latter never functioned as a system of dating or time reckoning; they were not expanded to include lay service; and families did not use their membership in the rota as a means to project their status in society at large. Moreover, many different rotas were in use in Babylonian temples, and there is no exact parallel for the Judean system of twenty-four divisions of one week each. In short, even if a Babylonian system possibly served as a model for the installation of rotational office in Jerusalem, the institution clearly assumed a shape and significance of its own. My purpose in this paper is to draw attention to the Babylonian system as an opportunity, and a challenge, for contextualizing Jewish temples.

\section{Prebends and Priestly Labor in Babylonian Temples}

\subsection{The Prebend System}

In Babylonian temples, the recruitment of priests was regulated through the prebend system. All male participants in temple ritual owned the legal title attached to a particular task. In scholarship, that legal title is known as the "prebend;" the Babylonian word is isqu, "lot, share." ${ }^{\text {Th }}$ The prebend included both

3 For the Egyptian phylai of the Old Kingdom, see Ann M. Roth, Egyptian Phyles in the Old Kingdom: The Evolution of a System of Social Organization, SAOC 48 (Chicago: The Oriental Institute of the University of Chicago, 1991); for those of the late period, see Willy Clarysse, "Egyptian Temples and Priests: Graeco-Roman," in A Companion to Ancient Egypt, Vol. 1, ed. A.B. Lloyd (Oxford: Oxford University Press, 2010), 274-9o (287).

4 I follow a narrow, legalistic definition of priesthood in this article, as elsewhere (Caroline Waerzeggers, The Ezida Temple of Borsippa: Priesthood, Cult, Archives, Achaemenid History 15 [Leiden: NINO, 2010], 34-38). It should be clear that not all professions that mediated between the sacred and non-sacred were included in the prebend system, such as prophets, diviners, and indeed all female cult attendants, some of whom had active roles in ritual acts; see Philippe Clancier, "Les activités des femmes dans les temples de Babylone aux époques hellénistique et parthe," in Femmes, cultures et sociétés dans les civilisations méditérannéennes et 
a right to income - in the form of foodstuffs, sacrificial remainders and other types of remuneration - and a duty to fulfil a function in the cult of the gods. As an example, we can cite the case of Nabû-êter, an inhabitant of Borsippa in the mid-sixth century BCE. This man owned a reedworker's prebend for five days per month in the Ezida temple. ${ }^{5}$ On those days, he was responsible for delivering reed mats and other items required in the cult of Nabû. On other days, his colleagues took over. Large sanctuaries employed several hundred priests, all specialists in particular areas of the cult, from baking bread to guarding the gates, and from weaving the garments of the gods to performing song and dance.

Inherent to the prebend system was a certain tension between public service and private interests. On the one hand, a prebend was always linked to a share of the temple's ritual program. It was in the interest of both the community and the priest himself that he performed that task diligently and punctually. On the other hand, the prebend belonged to the patrimony of his "father's house" (bitt-abi) and as such it was subject to legal and customary regulations intended to protect the rights of the ancestral family. Moreover, "pure" descent from a qualified priest featured among the ritual requirements for succession in priestly office. These dynamics mutually enforced each other and led to strong claims of the paternal family on both the prebend and on the rituals associated with it. ${ }^{6}$

\subsection{Hierarchy among Priests}

There were large differences in rank within the priesthood. In enumerative lists of temple personnel, the temple enterers always take precedence over the brewers, bakers, butchers, and minor priests who provided general service to the temple community, like gatekeeping and measuring staples. Although there is some variety in the detail of these lists, the general order of professions is consistent. Priestly hierarchy was defined by space, cultic activity, and purity.

proche-orientales de l'Antiquité, ed. F. Briquel-Chatonnet et al., Topoi Suppléments 10 (Cairo: Institut français d'archéologie orientale, 2009), 321-32; Rocío Da Riva and Gianluca Galetti, "Two Temple Rituals from Babylon," Jcs 70 (2018): 189-227. On the Neo-Babylonian prebend system, its historical roots and development, see G. van Driel, Elusive Silver: In Search of a Role for a Market in an Agrarian Environment: Aspects of Mesopotamia's Society (Leiden: NINO, 2002), 31-151.

5 вм 26564; this text will be published in a forthcoming study of the Atkuppu archive by Kathleen Abraham.

6 These dynamics were first discussed by Karlheinz Kessler, Uruk: Urkunden aus Privathäusern: die Wohnhäuser westlich des Eanna-Tempelbereichs, Teil 1, Ausgrabungen in Uruk-Warka, Endberichte 8 (Mainz am Rhein: Von Zabern, 1991), 72-73; see also more recently Bastian Still, The Social World of the Babylonian Priest, CHANE 103 (Leiden: Brill, 2019). 
Priests who drew nearest the cult image enjoyed the highest status and were also required to meet the highest purity standards. Lower ranking priests were confined to the courtyard and the surrounding workshops, while those further removed gradually fell outside the prebend system. The distinction between priestly and non-priestly activity had a spatial and transformational aspect to it. For instance, temple personnel who engaged in setting apart or modifying sacrificial substances (e.g. by selecting and measuring portions, by cooking, baking, merging, fermenting, milling, pressing, or slaughtering) held priestly status, while those who produced ingredients outside the temple (e.g. herdsmen, farmers) did not. Fishers and date gardeners brought their fresh produce into the temple and therefore required priestly status. Grain farmers delivered their harvest to a warehouse where it was first selected, measured out and passed on to millers and bakers. The farmers fell outside the prebend system, while those men who manipulated the sacrificial matter fell inside the system.

\subsection{Rotational and Non-rotational Office}

Definitions of prebends usually include time as an essential element of the system. For instance, according to Bongenaar, prebends were "characterized by three features: the profession, the period of service and the deity or temple for which the service is performed". ${ }^{7}$ Similar definitions have been put forward by other scholars. ${ }^{8}$ G. van Driel's definition of the prebend, uniquely, does not include the dimension of time. ${ }^{9}$ This omission is certainly intentional. In his study, van Driel emphasizes that both "divisible and undivisible" functions could be prebendary..$^{10}$ The difference between these two types of function is defined by the presence or absence of time in the prebend title, a distinction

A.C.V.M. Bongenaar, The Neo-Babylonian Ebabbar Temple at Sippar: Its Administration and its Prosopography, PIHANs 8o (Istanbul: Nederlands Historisch-Archeologisch Instituut, 1997), 140.

8 See, among others, Michael Jursa, Das Archiv des Bēl-rēmanni, PIHANs 86 (Istanbul: Nederlands Historisch-Archaeologisch Instituut, 1999), 4O; Rocío Da Riva, Der EbabbarTempel von Sippar in frühneubabylonischer Zeit (640-580 v. Chr.), AOAT 291 (Münster: Ugarit-Verlag, 2002), 313; Joan G. Westenholz, "Religious Personnel. Mesopotamia," in Religions of the Ancient World: A Guide, ed. S.I. Johnston (Cambridge, MA: Harvard University Press, 2004), 294.

9 "A prebend is defined here as a right to income deriving from the fulfilling of a function in the cult of the gods which involved contact with the divine and which was from the outset hereditary, or became so in the course of its development. In the remuneration the remains of the offerings placed before the gods concerned were of importance, but they were not reserved exclusively for those whom we will regard as prebendaries. Gender played a predominant role in the eligibility to office for the functions we will be concerned with" (G. van Driel, Elusive Silver, 34). 
that was already made by San Nicolò in 1934 for the Neo-Babylonian priesthoods and later by Charpin for the Old-Babylonian clergy.11 "Divisible" functions consist of the daily, repetitive menial tasks required for the continuous service of the gods, such as baking, brewing, herding, oilpressing, reedworking, measuring, gatekeeping, etc. These offices could splinter into smaller fractions simply by dividing the period of duty into smaller time periods. "Undivisible" functions, on the other hand, were not tied to a specific time of duty. Such appointments were perhaps to a certain extent honorary. In any case, they comprise the highest priestly positions at the level of erib-biti ("temple enterer"). Rank in these latter type of prebends was expressed through a daily standard of bread and beer, and a set portion of other sacrificial remains. For instance, a person could own a prebend "equaling three temple enterers;" this means that he enjoyed a triple portion of the standard amount of bread and beer. ${ }^{12}$ Such functions were divided, not by splitting up time slots, but by creating proportional shares of the income. ${ }^{13}$

The difference between non-calendrical and calendrical (essentially, rotational) offices was a fundamental principle of organization in the Babylonian priesthood. The non-rotational system applied to the highest ranks, i.e. priests who enjoyed direct access to the cult image. This group included the so-called "temple enterers," the lamentation singers, the goldsmiths, carpenters and others who had to carry out work on the statue of the god. The rotational system applied to all subservient priesthoods.

\section{$3 \quad$ Babylonian Priestly Courses}

The rotational nature of priestly office in Babylonian temples has received little attention in Assyriology, in contrast to the study of the mishmarot and mahlaqot of Second Temple Judaism. This is because priestly watches are less prominently present in cuneiform sources. For instance, we lack creation accounts comparable to the ones found in Chronicles or at Qumran, and we also lack evidence of priestly courses being used as time indicators or as markers of social status. However, the existence of priestly courses in Babylonian temples

\footnotetext{
11 Mariano San Nicolò, "Parerga Babylonica XII: Einiges über Tempelpfründen (isqu) und $\eta \mu \varepsilon p \iota ~ \lambda \varepsilon เ \tau o u p \gamma(x \alpha \iota$ in Eanna," ArOr 6 (1934): 180; Dominique Charpin, Le Clergé d'Ur au siècle d'Hammurabi, Hautes Études Orientales 22 (Geneva: Librairie Droz, 1986), 251.

12 See the discussion of the expression kì èrib bìti by Rocío Da Riva and Eckart Frahm, "Šamaš-šumu-ukīn, die Herrin von Ninive und das babylonische Königssiegel," AfO 46/47 (1999): 164 and by Da Riva, Ebabbar-Tempel, 332-33.

Van Driel, Elusive Silver, 67, 69, 71, 85-86.
} 
transpires in legal and administrative texts dealing with the practical side of cultic labor. These texts reveal that mid- and lower-level Babylonian priesthoods operated as rotational offices (Wechselamt) with short cycles of service, requiring their members to return for brief periods of duty at regular intervals throughout the year. Commitment to cultic service had a profound impact on the lifestyle of Babylonian priests as they were subject to purity laws for much of the year and could not leave their cities for long periods of time. Perhaps as a result of such restrictions, most priests led a stationary life in the vicinity of their temples and did not easily engage in activities that required some mobility, such as tax collecting or trade. ${ }^{14}$

The Babylonian term denoting the priestly watch is manzaltu, literally "station, stand." This word describes both the service obligation (or labor aspect of the prebend) and the shift (or its temporal aspect). ${ }^{15}$ The former use of the word is more commonly attested in late Babylonian texts. It can be found, for instance, in work contracts where a prebend owner hires a third party to perform his temple service or in receipts where sacrificial materials are delivered for use during a priest's tour of duty. Often the manzaltu is said to be due at a particular time, for instance in СT 22, 107, where a person's manzaltu is "drawing near" (CAD E, 69). More clearly temporal in implication are instances where periods of time are described as constituting somebody's manzaltu. vs 20, 87 lists seven shifts of the fishermen of Eanna under the heading "manzalätu of the fisherman's prebend," each of these manzalātu performed by a specific group of fishermen. This shows that manzaltu had a collective connotation as expected of a priestly watch. A similar instance is found in the fragmentary text AUWE 8,66, which stipulates that "somebody of his watch" (mannu ina manzaltišu, l. 6') will perform the cultic duty if a person is unable to serve himself. I will argue below that this collective aspect of the watch called for the appointment of a representative who could be held accountable for the performance of members within the priestly course.

14 Michael Jursa contrasts the rentier-type lifestyles of priests in the late Babylonian period to more entrepreneurial behaviours among non-priestly elites, see Aspects of the Economic History of Babylonia in the First Millennium BC. Economic Geography, Economic Mentalities, Agriculture, the Use of Money and the Problem of Economic Growth, Veröffentlichungen zur Wirtschaftsgeschichte Babyloniens im 1. Jahrtausend v. Chr., Vol. 4, AOAT 377 (Münster: Ugarit-Verlag, 2010), 265-95.

$15 \mathrm{CAD} \mathrm{M}_{1}, 228-29$, meaning 4. See also San Nicolò, "Parerga Babylonica XII," 185 ("Funktionsperiode", "Dienstschicht"); van Driel, Elusive Silver, 131 ("actual period of service") and Ran Zadok, Catalogue of Documents from Borsippa or Related to Borsippa in the British Museum, vol. 1, Nisaba 21 (Messina: Di.Sc.A.M., 2009), 78-79 ("service obligation", more specifically "service period, functional period, prebendal period of service, service shift"). 
It should be noted that manzaltu is related to mașsartu, a word discussed in detail by Yuval Levavi in this volume. The mașsartu is the totality of responsibilities assigned to and expected of a person or an institution. Priests, alongside administrative temple personnel, were tied to the mașartu of their temple or deity. But whereas the manzaltu denotes a specific tour of duty, the mașșartu seems to lack that concrete and temporal aspect; it rather denotes a general sense of work obligations and work ethic.

\section{$4 \quad$ The Rotas of the Lower Priesthoods}

As explained above, the division of calendrical prebends in the lower priesthoods was done by splitting up the period of service. Fragmentation was a natural consequence of social life, as heirs were entitled to a share of their father's estate, including his prebends. However, this predictable process of division was muddled by the irregular transactions of individual priests. Due to economic duress or the lack of progeny, it happened that a priest had to sell his prebend, donate it to a relative, exchange it against other property, or otherwise dispose of it. This means that the regular grid of the priestly orders was subject to change in at least two ways: non-heirs or outsiders could enter the rota, and unequal or irregularly spaced shares could form, due to sale, exchange, donation, etc.

Our sources mostly date from a time when regular and irregular division had fully progressed. It can be hard to see any logic in the rhythm of a single person's tour of duty. For instance, a certain Nabû-kāșir sold days o7, o8, and 28 of every month of the butcher's prebend in Ebabbar in the reign of Darius I. ${ }^{16}$ However, as I will show in this section, the original ownership patterns occasionally still transpire, revealing a variety of grids: some rotas turned on the trimester, others on the month, and still others on the fortnight. These rhythms determined how often and at which intervals priests had to perform their temple duty. The following overview shows that priesthoods working in the same temple could operate different rotas. ${ }^{17}$

16 Jursa, Bēl-rēmanni, 144-46.

17 Rocío Da Riva, "Pfründen in Eanna in der Zeit der Unruhe," AfO 50 (2003): 245-54 showed that in the reign of Nabopolassar, the bakers of Eanna operated different rotational shifts depending on the gods served: some gods were served in alternating shifts of 15 -days (the šapattu model), others in 10-day shifts $(10 / 10 / 10)$, still others in a combination of both models $(15 / 10 / 5)$. 


\subsection{The Trimestral Model: the Oxherds of Ezida}

The oxherds of Ezida originally operated in three watches that alternated every trimester in a fixed order. ${ }^{18}$ The first group was in office in months I-IV-VII-X (unit A), the second group in months II-V-VIII-XI (unit B) and the third group in months III-VI-IX-XII (unit C). The basic time unit of this Wechselamt was the trimester; the year was simply the repetition of four identical three-month cycles. There are indications that other Babylonian priesthoods made use of the same model, but the evidence is rather slim in their case. ${ }^{19}$

TABLE 3.1 Trimestrial rotation practiced by the oxherds of Ezida

\begin{tabular}{|c|c|c|c|c|c|c|c|c|c|c|c|c|}
\hline month & I & II & III & IV & V & VI & VII & VIII & IX & $\mathrm{X}$ & XI & XII \\
\hline unit & A & B & $\mathrm{C}$ & A & B & $\mathrm{C}$ & A & B & $\mathrm{C}$ & A & B & $\mathrm{C}$ \\
\hline
\end{tabular}

вм 82611+ (AchHist 15 no. 130) informs us how the roster worked. The text records the sale of a share of the oxherd prebend in the fourth year of king Nabopolassar. The share is described as follows: "Oxherd prebend in Ezida [temple of Nabû:] [4 days] — the 25th, 26th, 27th, 28th days of months I, IV, VII and $x-4$ days out of the days of Nabû-nādin-šumi (...)". According to the text, Nabû-nādin-šumi was a member of watch A, on duty in the first month of every trimester. In each of these months, Nabû-nādin-šumi performed his temple service on the same days. The statement that his prebend amounted to "four days" in total tells us that the turn of the rota offered the frame of reference here, not the year. Nabû-nādin-šumi owned 16 days per annum, but four days of his watch.

Originally, each watch of the Oxherds may have consisted of four tours of duty of seven days, with an additional slot covering the 29th and 3 th day at the end. This is based on the following text:

BM 109859 (AchHist 15 no. 129)

1. gišššb.ba lúsipa.gud.meš-ú-tu

2. é.zi.da é dpa ina 7.ud.meš.meš

3. šá Ina-din a lúsipa.gud.meš $1^{e n} u_{4}-m u$

18 This section on the oxherds of Ezida summarizes the discussion in Waerzeggers, Ezida, 275-81.

19 Erlend Gehlken, Uruk: Spätbabylonische Wirtschaftstexte aus dem Eanna-Archiv Teil II, Ausgrabungen in Uruk-Warka, Endberichte 11 (Mainz am Rhein: Von Zabern, 1996), 62-63 n. 16 has considered the possibility that the rhythm I-IV-VII-X, II-V-VIII-XI, III-VI-IX-XII found in some administrative texts attests to an original trimestrial system in Eanna. 
4. ki-i 1/2 ma.na 5 gín kù.babbar [kù].pad.du

5. Idag-ki-šir a lú[sipa.gud.meš]

6. ki Ina-din a lúsipa.[gud.meš ki.lam]

7. im-bi-e-ma i-šam

"An oxherd prebend (in) Ezida, the temple of Nabû-one day in the ' 7 -days' of Nādinu of the Oxherd family: Nabû-kēšir of the [Oxherd family] named 35 šeqels of block silver as its purchase price with Nãdinu of the Oxherd family and bought it".

This text suggests that Nādinu was on duty during seven days of the rota (l. 2). Unless the two plural markers (meš) on "seven days" (7.ud.meš.meš) are a scribal mistake, the use of an additional plural marker indicates that "7-days" was a countable unit in the roster of the oxherds. If we combine this information with the evidence from вм 82611+, it would appear that in the time of Nabopolassar each watch of the oxherds was divided in five slots, i.e. four slots of seven days and an fifth slot of two days at the end of the month: days 1-7, days $8-14$, days $15-21$, days $22-28$, days $29-3$ o.

\subsection{The Monthly Division Scheme}

The rota used by the bakers of Ezida was different from the one used by the oxherds in the same temple. ${ }^{20}$ While the oxherds rotated on a three-monthly basis, the bakers did so on a monthly basis. Only faint traces of this system are visible in the priestly archives from Borsippa. BM 28918 (AchHist 15 no. 9o; late 6th century BCE) is a case in point:

The baker's prebend in Ezida, temple of Nabû, of Šaddinnu son of Balassu from the Bēliya'u family:

- days $02,04,20$ of every month of the entire year: offering to the god

- 19-I: offering

- 19-X: offering

- 17-III: offering

- 17-VIII: offering

- 17-IX: offering

- 17-XII: offering

- O4-III: one meal, second entry, offering

In total: $31 / 2$ days of the days of Nabû. 
Šaddinnu's share in the service of Nabû totalled "3 $1 / 2$ days" according to this text. Expressed in calendar days, however, his share was much larger: it comprised 42 days. $^{21}$ The total figure of " $31 / 2$ days" can only be explained if the month served as the yardstick of prebend calculation among the bakers $(12 \times 31 / 2=42)$. Just as the "four days of the oxherd prebend" in вм 82611+ equalled 16 calendar days of service as a result of the trimestrial rota, so did Šaddinnu's share of " $31 / 2$ days" before Nabû equal 42 calendar days because the month was taken as the point of reference.

It should be noted that there was not a single month when Šaddinnu actually served exactly $31 / 2$ days before Nabû: during six months of the year he served three days and during the other six months he served four days. The advantage of this system of division was that half-day service periods were avoided in practice. Note that the manner in which that nominal "half day" was carved out in the roster (19-I, 19-X, 17-III, 17-VIII, 17-IX, 17-XII) is reminiscent of the trimestrial system used by the oxherds. Days 19-I and 19-X belong to watch A, days 17-III, 17-IX, 17-XII belong to watch $\mathrm{C}$ and 17-VIII to watch $\mathrm{B}$. The introduction of the trimestral cadence into the monthly roster was a strategy to avoid the creation of half-day service periods.

\subsection{Twenty-four Shifts: the šapattu Model}

A widespread type of Wechselamt in Babylonian temples was a roster consisting of 24 service shifts per year, alternating every fortnight (šapattu). ${ }^{22}$ The first course (unit A) was on duty during the first fifteen days of every month (days $01-15$; šapattu mahrītu) and the second course (unit B) during the last fifteen days of every month (days 16-30; šapattu arkitu).

21 On one of these days (o4-III) Šaddinnu was responsible for two servings.

22 I will focus my discussion on the bakers and oilpressers of Ebabbar, where the system is well-documented, but this type of roster was widely used in Babylonia. For brewers of Ebabbar operating in 15-day shifts, see John MacGinnis, Letter Orders from Sippar and the Administration of the Ebabbara in the Late-Babylonian Period (Poznań: Bonami, 1995), no. 168: 6. For the butchers of Ebabbar, see Caroline Waerzeggers, Marduk-rēmanni: Local Networks and Imperial Politicis in Achaemenid Babylonia, oLA 233 (Leuven: Peeters, 2014), no. 16: 13'. For the brewers of Larsa, see Michael Jursa, "Pfründendienstperioden," $N A B U$ 1996/42. Evidence for 15-day service periods in Borsippa is scarce (Bм 29539: 6-7 ta ud.1.kam en ud.15.kam qé-ri-bi šá d 30 "from day o1 until day 15, offering to Sîn"), but see the title bél-šapatti discussed below. The preference of $21 / 2,5$ and $71 / 2$ day service periods among the brewers of Nippur also suggests that they operated on a šapattu basis, see Paul-Alain Beaulieu, "The Brewers of Nippur," Jcs 47 (1995): 87. The Nabû-ušallim archive attests to the 15-day service period among the bakers of Eanna in Uruk, e.g. Hermann Hunger, "Das Archiv des Nabû-ušallim," BaM 5 (1970): 193-304 (no. 25). 
TABLE 3.2 The šapattu model consists of two alternating watches of 15 days each, or 24 service shifts per year

\begin{tabular}{|c|c|c|c|c|c|c|c|c|c|c|c|c|c|c|c|c|c|c|c|c|c|}
\hline \multicolumn{2}{|c|}{ I } & \multicolumn{2}{|c|}{ II } & \multicolumn{2}{|c|}{ III } & \multicolumn{2}{|c|}{ IV } & \multicolumn{2}{|c|}{ V } & \multicolumn{2}{|c|}{ VI } & \multicolumn{2}{|c|}{ VII } & \multicolumn{2}{|c|}{ VIII } & \multicolumn{2}{|c|}{ IX } & \multicolumn{2}{|c|}{$\mathrm{X}$} & XI & XII \\
\hline A & B & A & B & A & B & A & B & A & B & A & B & A & B & A & B & A & B & A & B & A $\mathrm{B}$ & A \\
\hline
\end{tabular}

The best evidence for this roster comes from the dossier of the oilpressers preserved in Ebabbar's large temple archive. Bongenaar reconstructed their rigidly alternating shifts: ${ }^{23}$ Mušēzib-Marduk, the šangû of Sippar, and his heirs were on duty in every second half of the month and another group was on duty in every first half of the month.

An important aspect of this roster has been overlooked by Bongenaar. The organization of the oilpresser's prebend in two alternating shifts was introduced at a fairly late date in Ebabbar's history, in the tenth year of Nabonidus, to be exact. Before that time, the oilpressers were organized in an entirely different fashion, probably not even as a prebendary profession. This renders the oilpresser's dossier of Ebabbar extremely valuable as it takes us to the origins of the system, when the rota was first implemented. It allows us to observe the rota in its pure form, before sale, exchange and inheritance had affected it. ${ }^{24}$

At least two priesthoods of Ebabbar already operated according to the šapattu system before it was introduced for the oilpressers. The evidence for the brewers is not optimal and I will not further explore it here (see n. 22 above), but it is worthwhile taking a closer look at the dossier of the bakers. There, we encounter the šapattu system in a mature state of development, some generations after it was first implemented.

One of the earliest texts about the šapattu system of the bakers of Ebabbar is вм 114772, dated in the tenth year of Nabopolassar (616 вС ). ${ }^{25}$ The bakers listed in this text owned double, single or half šapattu shares consisting of respectively 30,15 and $71 / 2$ days. vs 6206 (611 вСE) shows that the šapattu system was combined with the rhythm of the maššartu calendar: " 2 half šapattu shares in months IX-X-XI-XII (...) of PN". ${ }^{26}$ According to CT 57, 325 (583 BCE) four bakers

23 Bongenaar, Ebabbar, 286.

24 The re-organization of the oilpressers of Ebabbar is discussed at greater length in Waerzeggers, Marduk-rēmanni, 62-65.

25 Da Riva, Ebabbar-Tempel, 321.

26 In Neo-Babylonian temple administration, the word maššartu is used both to indicate the periodic payments of sacrificial ingredients to temple personnel and to indicate the time period itself. The length of one maššartu period varied from temple to temple. In the Ebabbar temple, the year counted three maššartu periods of four months each (Bongenaar, Ebabbar, 171). 
owned two full šapattu periods each $(4 \times 2 \times 15$ days $)$ in the third maššartu period of the year (months IX-X-XI-XII). BM 60485, dating from Nabonidus' reign, ${ }^{27}$ shows the progressive fragmentation of this roster as most bakers now owned only half šapattu periods ( $71 / 2$ days), while full ones ( 15 days) had become rare and double shares (3o days) did no longer exist.

None of these texts specifies the calendar days included in an individual baker's šapattu share. A plausible assumption would be that a baker who owned one šapattu period officiated during one half month (15 consecutive days), and that a baker who owned half a šapattu period officiated during a quarter month ( 7 1/2 consecutive days). This assumption has been proven wrong by Michael Jursa on the basis of a text from the reign of Darius I. ${ }^{28}$ The baker in this text owned two šapattu periods, or 30 days. However, these days were not owned en bloc, but were spread evenly throughout the year in small portions:

$23,24,29,30$ of month I

$23,24,29,3$ of month II

$23,24,29,3$ o of month III

$23,24,29$ of month IV

(subtotal: 15 days in the maššartu of month I)

29, 30 of month $\mathrm{V}$

29, 3 o of month VI

29, 30 of month VII

29 and half of 30 of month VIII

(subtotal: 7 1/2 days in the maššartu of month $\mathrm{V}$ )

27,28 of month IX

27,28 of month $x$

27,28 of month XI

27 and half of 28 of month XII

(subtotal: 7 1/2 days in the maššartu of month IX)

total: two šapattu periods of the baker's prebend

This text shows that, in addition to the fortnight, the quarter year served as a line of division in this roster. One šapattu-share no longer coincided neatly with one fortnight in a calendrical sense, but it was divided in smaller portions and spread equally among the four months of a maššartu period. This system prevented a person from serving only during one period of the year. The priest

27 Edited by Bongenaar, Ebabbar, 167-68.

28 вм 42299 (Jursa, Bēl-rēmanni, 129-30 and 54-55). 
of в 42299 was called up every month, despite the fact that his prebend consisted only of two fortnights. ${ }^{29}$

TABLE 3.3 The šapattu-maššartu scheme of the bakers of Ebabbar

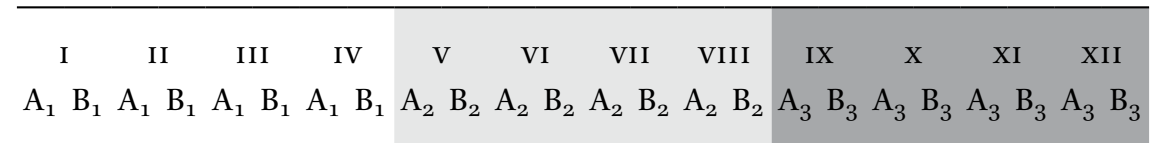

4.4 Eight Priestly Courses: the Fortnight Combined with the Quarter Year Ezida's gatekeepers operated 8 shifts of 15 days, one turn of the roster being completed after four months (AchHist 15 no. 25).

TABLE 3.4 The eight 15-day shifts of the gatekeepers of Ezida

\begin{tabular}{|c|c|c|c|c|c|c|c|c|c|c|c|c|c|c|c|c|c|c|c|c|c|}
\hline \multicolumn{2}{|c|}{ I } & \multicolumn{2}{|c|}{ II } & \multicolumn{2}{|c|}{ III } & \multicolumn{2}{|c|}{ IV } & \multicolumn{2}{|c|}{$\mathrm{V}$} & VI & \multicolumn{2}{|c|}{ VII } & \multicolumn{2}{|c|}{ VIII } & \multicolumn{2}{|l|}{ IX } & $\mathrm{x}$ & \multicolumn{2}{|c|}{ XI } & \multicolumn{2}{|c|}{ XII } \\
\hline A & B & $\mathrm{C}$ & $\mathrm{D}$ & $\mathrm{E}$ & $\mathrm{F}$ & G & $\mathrm{H}$ & A & B & $C D$ & E & $\mathrm{F}$ & $\mathrm{G} \quad \mathrm{H}$ & $\mathrm{H}$ & A B & $B \quad$ & $\mathrm{C} \quad \mathrm{D}$ & $\mathrm{E}$ & $\mathrm{F}$ & $\mathrm{G}$ & $\mathrm{H}$ \\
\hline
\end{tabular}

\subsection{Three Courses per Month}

Yet another division scheme was used by the temple fishers of Eanna in Uruk. YOs 7, 12 shows that they worked in three watches, each consisting of six fishers who took turns every ten days. The first group of six was on duty from day o1 to 10 of every month, the second group from day 11 to 20 , and the third group from day 21 to $30^{30}$ This roster appears to have replaced an earlier one consisting of six 5 -day shifts of which the last one was split in two (days $26-27-28+29-30$ ). ${ }^{31}$

29 This phase in the progressive division of the baker's prebend is also documented by BM 43178+ (Jursa, Bèl-rēmanni, 228-229): "days 17 and 18 of month IX, 17 and 18 of month X, 17 and 18 of month XI and 17 and half of day 18 of month XII-in total $71 / 2$ days in the maššartu period of month IX, in the second half (šapattu) of the month, baker's prebend in Ebabbar ..."; see also Jursa Bēl-rēmanni, 56 .

$30 \quad$ San Nicolò, "Parerga Babylonica XII," 182-83; Helmut Freydank, "Zu den Einkommensrechten und Dienstleistungen in Eanna," in Festschrift Lubor Matouš I, ed. B. Hruška and G. Komoroćzy (Budapest, 1978), 91-103; Kristin Kleber, "Die Fischerei in der spätbabylonischen Zeit," WZKM 94 (2004): 135.

31 This roster is attested in vs 20,87 . Scholars have put forward different explanations for the apparent simplicity of the later roster (regular 10-day shifts in yos 7,12 ) compared to the earlier one (irregular 5 -day shifts in vs 20, 87). Freydank suggests that the Eanna temple re-designed and simplified the roster at a certain point ("Einkommensrechten," 98), while Kleber suspects that the re-grouping of shares was the result of inheritance without the interference of the temple ("Fischerei," 137). 
TABLE 3.5 Three 10-day shifts per month (YOS 7,12$)$

\begin{tabular}{llll}
\hline $\begin{array}{lll}\text { days of the month } \\
\text { unit }\end{array}$ & A1-10 & $11-20$ & $21-30$ \\
& A & B & C \\
\hline
\end{tabular}

TABLE 3.6 Six 5-day shifts per month (vs 20, 87)

\begin{tabular}{llllllll}
\hline days & O1-05 & o6-10 & $11-15$ & $16-20$ & $21-25$ & $26-28$ & 29,30 \\
unit & A & B & C & D & E & $F_{1}$ & $\mathrm{~F}_{2}$ \\
\hline
\end{tabular}

This model has some affinity with the 7-day units of the Oxherds, who also added a slot of two separate days at the end of the month.

\section{$5 \quad$ Rotation in the Higher Priesthoods}

We have seen that in the higher priesthoods prebends did not prescribe a particular period of service. How did such priesthoods operate in practice? Only scant evidence is available, but two texts from two different cities show that shortly ahead of time, a temple authority proclaimed in a sealed document who was to serve in the up-coming rota. BM 77834 , edited by Bongenaar, is the most informative of these two texts. ${ }^{32}$ The tablet is said to be a copy of another, sealed tablet that had been issued by the šangû of Sippar and in which he had fixed the rota of the temple enterers of Šamaš for one year (Nbp o7; 619 BCE). Each month was assigned to a person from a different ancestral family and each family was represented by only one delegate. How these families decided whom to send, is unknown. Given the original meaning of isqu "lot", it is possible that the procedure involved the casting of lots, but this is entirely speculative. Because no other temple enterers are attested at Ebabbar in this

32 Bongenaar, Ebabbar, 153-54. Note that my interpretation of this text differs in a crucial aspect from that of Bongenaar (ibid.), Jursa (Bēl-rêmanni, 54 n. 198) and MacGinnis ("Review of The Neo-Babylonian Ebabbar Temple at Sippar: Its Administration and Its Prosopography by A.C.V.M. Bongenaar," JAOS 120/1 [2000]: 63-67 [65]) who consider this text as proof that at the beginning of the Neo-Babylonian Empire the service periods of the temple enterers were unfragmented and therefore recently implemented. Temple enterer prebends did not operate under the same principles of fragmentation as those in the lower priesthoods, as explained above. In my opinion, this text offers proof that practical arrangements had to be made in order to organize the work in these types of priesthoods. 
period, apart from those mentioned in the list, ${ }^{33}$ the purpose of the text must have been to establish an order of performance between the various families, rather than to establish the identity of those due to serve. Interestingly, the text provides a thirteenth slot for an extra month Addaru. As the tablet is dated in the third month, it could not yet have been known at the time when the text was issued whether or not such a thirteenth shift would be needed.

A similar procedure is attested in a text from Babylon which records a proclamation by the šatammu of Esagil (chief administrator) about the service shift of the temple enterers of a minor deity. ${ }^{34}$ The text specifies who will be on duty during four tours of duty (days $01-05,06-15,16-20,21-30$ ). The text is an official record, as it displays the šatammu's seal prominently on the reverse, ${ }^{35}$ but it is not a standard legal text as it lacks witnesses, the scribe's name and a date. It also fails to indicate how long this arrangement will remain valid. Interestingly, Esagil's šatammu assigned one of the service periods to an extended family, "the house of Bittanu", apparently because no delegate was known at the time. Like в м 77834 , this suggests that the rights belonged to an ancestral group and that the service was performed by an available member of the family.

Creation, Development and Suspension of Watches

\subsection{The Role of the King}

Who created the priestly watches, and when? In the books of Chronicles, the creation of the mishmarot is attributed to King David. To my knowledge such creation stories are absent from Babylonian literature, except perhaps in the Epic of Creation (see below). There can be no doubt, however, that the implementation of new rosters was in practice a royal affair in Babylonia. In 546 в $\mathrm{CE}$, during the reign of Nabonidus, the oilpressers of the Ebabbar temple were elevated to priestly status; henceforward they assumed rotational office, operating in 15-day shifts (see above). One of the two watches was assigned to Ebabbar's chief administrator (šangûu), no doubt as an honorary entitlement. These changes took place at the time when Nabonidus was carrying out other reforms at Ebabbar aimed at bringing the temple under greater royal control. ${ }^{36}$

33 Da Riva, Ebabbar-Tempel, 334.

34 Heather D. Baker, The Archive of the Nappāhu Family, AfOB 30 (Vienna: Institut für Orientalistik, 2004), no. 73 .

35 See the drawing of the reverse by Baker, Nappāhu, 401.

36 Bongenaar, Ebabbar, 57-58. 
A more explicit instance of the king's agency in creating new priesthoods comes from yos 6,10, which records an order by Nabonidus to initiate ten new fishermen to prebendary service in the Eanna temple of Uruk. This order was transmitted shortly after Nabonidus celebrated his first Akītu festival, while he was on tour in southern Babylonia. ${ }^{37}$ The installment of the new fishermen was part of a larger program meant to improve cultic provisions at Eanna. Earlier, Nabopolassar had dedicated a range of new priests to the "offering table" of Ištar-of-Uruk and Nanāya. ${ }^{38}$

\subsection{The Role of the "House of the Father"}

Like with the priestly watches of Jerusalem's Second Temple, the paternal family was closely associated with the rotas of Babylonian priests. This association manifests itself at two levels of kinship: the larger descent group or ancestral family, and the smaller kinship group known as bït-abi, "father's house".

At the level of the clan, these claims can be seen in the long-lasting association between ancestral families and certain tranches of the temple's ritual program. In Borsippa, the entire oxherd prebend was the property of a single clan, and each of the three watches of the trimestral rota was associated with a particular branch of the clan. These three branches kept their distinctive claims intact across generations, so that temple service can be used as an indicator of genealogical structure, and vice versa. ${ }^{39}$ Even in larger priesthoods we seldom find more than a handful of families attached to the same service. At Borsippa, over one hundred bakers were employed at the Ezida temple, but these men belonged to only four clans: the Beliya'u, Kidin-Sîn, Nabu-mukīn-apli and Šèpē-ilia families. One of these clans even supplied more than half of all active bakers.

Such continuity was possible thanks to several interlocking dynamics that enforced patrilineality. The inheritability of prebends and the requirement for active priests to descend from a priest were discussed earlier in this article. Another important aspect was the paternal family's right of redemption. This

37 On this text and its historical background, see Mariano San Nicolò, Beiträge zu einer Prosopographie neubabylonischer Beamter der Zivil- und Tempelverwaltung (Munich: Bayerische Akademie der Wissenschaften, 1941), 65-70; Denise Cocquerillat, "Recherches sur le verger du temple campagnard de l'Akītu (KIRI 6 hallat)," wo 7 (1973): $96-134$ (112); Paul-Alain Beaulieu, The Reign of Nabonidus, King of Babylon (556-539 B.C.), YNER 10 (New Haven: Yale University Press, 1989), 118-19; van Driel, Elusive Silver, 55 n. 4, 73, 100 n. 9; Paul-Alain Beaulieu, The Pantheon of Uruk during the Neo-Babylonian Period, CM 23 (Groningen: Styx, 2003), 74.

38 Elizabeth E. Payne, The Craftsmen of the Neo-Babylonian Period: A Study of the Textile and Metal Workers of the Eanna Temple (PhD diss., Yale University, 2007), 229-30.

39 Waerzeggers, Ezida, 286. 
right was exercised by a lower-level kinship group known as the father's house, or bit-abi. The right of redemption is illustrated by a text from Dilbat. A certain Qišti-Marduk of the Egibi family had sold a temple enterer's prebend in the temple of Dilbat to a certain Kudurrānu of the Šangû-Dilbat family. Later, a relative of Qišti-Marduk, a member of the Egibi family, contested that transaction, saying: "That prebend belongs to my bitt-abi." Subsequently, this man bought the prebend back from Kudurrānu, bringing the prebend back into the Egibi family. ${ }^{40}$ Evidence from Borsippa shows that it was not uncommon for prebendaries to exercise their right of redemption based on their membership to the bit-abi which held the original property rights. ${ }^{41}$

Broad similarities exist between the bit-abi of the Babylonian texts and the beit-ab in biblical and rabbinic literature dealing with the twenty-four courses in Jerusalem. In Judea as well as Babylonia, the right to perform ritual labor was transferred from the larger clan to the individual through an intermediate kinship group called the house of the father. These extended family units were placed under the leadership of one member, in Judea known as the head of the house of the father, in Babylonia known as the big brother (i.e. the eldest son of the eldest son of the common ancestor). The big brother held special responsibility towards the temple service of his family; when a relative neglected his duties, or when he was unable to perform them, it fell to the big brother to arrange a replacement.

All known rotas are based on the normative calendar of 360 days, or twelve 3o-day months. This idealized calendar, which disregards the alternation between 29- and 30-day lunar months, was already used by the earliest Mesopotamian bureaucracies as a means to normalize the irregularities of lunar time for the purpose of book-keeping and calculation, and it remained in use until the Seleucid period..$^{42}$ Neo-Babylonian priests used this 360 -day calendar to calculate and divide their prebends. However, because the cultic activities

\footnotetext{
$40 \quad$ JCS 36, 19 and duplicate OECT 10, 398.

41 Waerzeggers, Ezida, 83-84. For a discussion of the bitt-abi in early Neo-Babylonian elite society, see John P. Nielsen, Sons and Descendants: a Social History of Kin Groups and Family Names in the Early Neo-Babylonian Period, 747-626 B.C., CHANE 43. (Leiden: Brill, 2011).

42 Lis Brack-Bernsen, "The 36o-day Calendar in Mesopotamia," in Calendars and Years: Astronomy and Time in the Ancient Near East, ed. J.M. Steele (Oxford: Oxbow Books, 2007), 83-100; Sacha Stern, Calendars in Antiquity: Empires, States, and Societies (Oxford: Oxford University Press, 2012), 87-88.
} 
in the temple were based on real month lengths, the ideal 36o-day calendar needed adjustment in practice. Roughly six of the twelve 3oth days provided by the ideal rota were fictitious, as almost half of the months of a synodical year count 29 days. ${ }^{43}$ Moreover, the prebendal calendar did not take the extra VIth or XIIth month of leap years into account.

\subsection{The 3oth Day of the Month}

There are many examples of the use of the schematic 30-day month for the partition of prebends in the Neo-Babylonian period. All the rotas discussed above are based on this system. In Dilbat, there existed a hallatu garden of the "3oth day" which shows that the rab-banutu (date gardener's) prebend was parceled out on the basis of the 30-day month. ${ }^{44}$ In Babylon, the monthly roster of the priests of Išhara was designed on a 30 -day basis, ${ }^{45}$ and so was that of the fishers of Uruk's Eanna temple. ${ }^{46}$ In Borsippa, a text like vs 6173 , which assumes a fixed period of 8 days between the 3oth and 7 th days of every two consecutive months of the year, shows that here, too, the prebendal calendar was based on the 30-day month. In fact, every prebend title for the 3 oth day illustrates the normative 360 -day calendar, as the same month is never full every year. ${ }^{47}$

Strategies must have been in place to by-pass this essential flaw in the system. The unpredictable alternation of 29 and 3o-day months is known to have caused confusion in cult practice, ${ }^{48}$ and there must have been a system in place to remedy the inherent unfairness of the 36o-day calendar. It could be suggested that the prebend of the 3oth day was cheaper, or generated

43 On month lengths in first millennium вс Babylonia, see Paul-Alain Beaulieu, "The Impact of Month-lengths on the Neo-Babylonian Cultic Calendar," ZA 83 (1993): 6687; John M. Steele, "The length of the month in Mesopotamian calendars of the first millennium BC," in Calendars and Years: Astronomy and Time in the Ancient Near East, ed. J. M. Steele (Oxford: Oxbow Books, 2007), 133-48; Stern, Calendars, 71-124; Mathieu Ossendrijver, "Babylonian Scholarship and the Calendar During the Reign of Xerxes," in Xerxes and Babylonia: the Cuneiform Evidence, ed. C. Waerzeggers and M. Seire, oLA 277 (Leuven: Peeters, 2018), 135-63.

44 Cocquerillat, "Recherches."

45 Baker, Nappāhu, nos. 67 and 73 .

46 Freydank, "Einkommensrechten."

47 E.g. вм 42299 (Jursa, Bēel-rēmanni, 129); вм 42365 (Jursa, Bēl-rēmanni, 161), вм 43098+ (Jursa, Bēl-rēmanni, 223; "last 15 days of III and XI"), AUWE 8 no. 89, вм 29419, Bм 28863, вм 27788, вм 94586, вм 26509, вм 265о2, вм 25125 .

48 CT 22, 167, cited by Bongenaar, Ebabbar, 21-22: a herdsman of the regular offerings asks the temple administrator of Sippar whether the present day is the first day of the new month, or the 3oth day of last month. See also Beaulieu, "Impact," 70-71 and Stern, Calendars, 83 on this letter. 
less income, than that of the other days of the month, but we lack the necessary comparative data to substantiate this suggestion. In fact, there are indications to the opposite. Denise Cocquerillat's research on the size of the hallatu gardens in Dilbat has shown that as much land was attached to the rab-banutu prebend of the zoth day as to that of any other day of the month, which suggests that all the days of that prebend had the same value. ${ }^{49}$ There are not enough quantifiable data to pursue this further. A text like Bм 94586 (AchHist 15 no. 185), in which days 28-29-30 of month IX of the oxherd prebend were exchanged against three other ones, might have given us a clue, but the tablet is broken at the crucial place and we do not know for which days the prebend was exchanged. In vs 2087 , the fishers of Eanna are said to operate in five-day shifts, but the sixth one is split in a period of three days (26-27-28) and of two days $(29-30)$. This may have served a purpose with regard to irregular month lengths.

A practical solution to this problem can be found in UET 4, 161, where the temple service of the 3oth day is assigned to a collective body of priests (ina karê) rather than to an individual. This would require the team to make collective arrangements and to share in the duties and rights of the irregular last day of the month. Another system, that of "deductible days", was in use in the third and second millennia вСE: ${ }^{50}$ it required priests on duty on the 3 th day to forfeit their rights and refund excess commodities in hollow months. The following short note from Neo-Babylonian Borsippa which lists rations for only the 3 oth days of certain months may have its background in such a system, though we cannot be certain of the prebendary nature of the rations:

$$
\begin{aligned}
& \text { BM } 29321(98-11-12,497) \\
& \text { 1. ud.3o.kam šá }{ }^{\text {itizíz }} \\
& \text { 2. ud.3o.kam šá }{ }^{\text {itibára }} \\
& \text { 3. ud.3o.kam šá itine } \\
& \text { 4. pab } 3^{\text {ta } ̌ \text { šuk.hi.a }}
\end{aligned}
$$

Translation: "3O-XI, 30-I, 30-V; in total 3 rations"

\subsection{The 13th Month of Leap Years}

Another shortcoming of the normative calendar of 360 days is that it does not take intercalary months into account. On average, one year in three counted

49 Cocquerillat, "Recherches."

50 Karel Van Lerberghe and Gabriela Voet, Sippar Amnānum: The Ur-Utu Archive I (Ghent: Ghent University Press, 1991), 50; Walther Sallaberger, Der kultische Kalender der Ur III-Zeit (Berlin: De Gruyter, 1993), 11 n. 34; Brack-Bernsen, “36o-Day Calendar," 93. 
13 months instead of 12, but we never hear of priests holding prebends for intercalated days. A text like ҮвС 3991, which gives a list of all the prebend days owned by Urukean bakers and brewers in the temple of Larsa, clearly shows that no formal arrangements existed for the temple service of the 13th month. ${ }^{51}$ How were priests called to duty in the extra month of leap years?

It seems that arrangements for the temple service of intercalary months were made ad hoc. Yos 6, 241 contains the schedule of the service (manzaltu) of the bakers and brewers of the Lady-of-Uruk, Nanāya and Bēltu-ša-Rēš in Uruk for the first five days of an upcoming intercalary month. ${ }^{52}$ The tablet was written on Nbn 25 -XI-12, about a month before the service was due. ${ }^{53}$ It assigned the service of the brewer's prebend (man-zal-tu $u_{4}$ lúlùnga-ú-tu, l. 2-3) to the

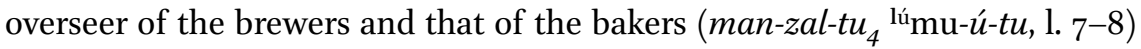
to three individual bakers. The text is sealed but not witnessed, indicating that it was an internal, but officially ratified document. It shows that there were no pre-existing arrangements for cultic service in an intercalary month and that special arrangements had to be made with members of the various priesthoods shortly ahead of time, probably as soon as the temple administrators had been notified by the royal bureaucracy about the upcoming intercalation.

Another piece of evidence relating to cultic service in the 13th month of a leap year comes from Borsippa. In Dar 19, Šaddinnu contracted a person to do the preparatory work of the baker's service on two days of the intercalary ulülu of that year, a third of day 17 and a sixth of day $19 .{ }^{54}$ In contrast to other lease contracts of the baker's prebend, this was not an arrangement meant to last for a long time. Its validity was limited to the two said days of the upcoming intercalary month. The fact that a separate contract had to be drawn up, indicates that the ordinary roster did not cover intercalary days automatically. ${ }^{55}$

It was certainly no coincidence that Šaddinnu was involved in the bread offerings of the 17 th and 19th days of the intercalary month. We know that he owned the 17th and 19th days of several months of the year and the third and

51 увс 3991 was published by Paul-Alain Beaulieu, "Prébendiers d'Uruk à Larsa," $R A 87$ (1993): 137-52.

$5^{2}$ Editions by San Nicolò, "Parerga Babylonica XII," 183; Beaulieu, Pantheon, 172 (with collations).

53 The twelfth year of Nabonidus had an intercalary xiIth month, see Richard A. Parker and Waldo H. Dubberstein, Babylonian Chronology 626 B.C. - A.D. 75. (Providence, RI: Brown University Press), 29.

54 BM 29115 (AchHist 15 no. 92).

55 A similar arrangement is documented in вм 29486 Dar 16 where Šaddinnu contracted an ēpišānu for three months, including an intercalary one (l. 3-4: ul-tu itiše igi ${ }^{u}$ šá mu.16 a-di itibára šá mu.an.na.17?.kam I da-ri-ia-muš). A provisional arrangement for the thirteenth month is Bм 77834 (Bongenaar, Ebabbar, 153-54), discussed above. 
sixth share of these days in VIb mentioned in BM 29115 correspond exactly to a twelfth of his total yearly duty on these days. ${ }^{56}$ This suggests that clerical service in the intercalary month was modeled on patterns available from the regular calendar. This was also the case for the oilpressers of Ebabbar whose 15-day work shifts simply kept rotating along the established pattern whenever an intercalary month came up. ${ }^{57}$ It remains unclear how other rosters, such as the trimestral rota of the oxherds of Ezida, were adapted to accommodate service in the 13th month.

The extra-ordinary status of the 13th month also transpires from administrative temple records. Payments to prebendaries for the offerings of the 13th month were made separately, generating a separate accounting track. This transpires in the administrative practices of the Ebabbar temple of Sippar, ${ }^{58}$ but there is also evidence from Borsippa. In вм 28898 the bakers and brewers of Ezida received pappasu solely for the 13th month. ${ }^{59}$ The 13th month often was the time when accounts were made (e.g. BM 17719, AchHist 15 no. 27).

Control, Performance and Authority

\subsection{Ledgers}

The temple administration kept track of the progressive division of prebends and their ever-changing ownership patterns on wooden ledgers. These wax boards have not been preserved, but they are sometimes referred to in clay tablets. ${ }^{60}$ When a prebend was transferred to a new owner by inheritance or

$5^{6}$ See вм 28918 (AchHist 15 no. 9o) which was discussed above in the context of the monthly rotation model of the bakers of Ezida.

57 A similar arrangement is suggested by вм 42551+ (Jursa, Bèl-rēmanni, 198-99), an account between a baker and his performer for having done service on four days a month during the past "six months" (l. 10, 15) "from month III til month vII" (l. 1-2) in a year with an intercalary vith month (Dar 19).

$5^{8}$ вм $75^{809}$ (discussed in detail by Bongenaar, Ebabbar, 238) is a settlement of accounts between an overseer and a priest for the intercalary addaru of Cyr o6. Cyr. 31 contains the accounts of sattukku (sacrificial supplies) and pappasu (income) of four years from Cyr o1 to Cyr o4, listing the data of two intercalary months separately on the reverse (Bongenaar, Ebabbar, 143). Camb. 300 records a supply of barley for the offerings in the intercalary addaru of Camb o5; the delivery is labeled as the maššartu of XIrb (l. 9), showing that this month constituted a separate unit of accounting. An interesting text, finally, is CT 56 , 192 which shows that payment of prebendary remuneration for service in the intercalary month could lag behind several years.

59 Ст 56, 233 offers a parallel from Sippar.

6o On the use of waxed writing boards in Neo-Babylonian temples, see John MacGinnis, "The Use of Writing Boards in the Neo-Babylonian Temple Administration at Sippar," 
sale, the name of the old owner (bél-isqi) was erased on the ledger's wax surface and replaced with the name of the priest who was to replace him. This procedure is documented in yos 7, 167, a tablet from the Eanna archive of Uruk. ${ }^{61} \mathrm{~A}$ freshly appointed brewer of the Lady-of-Uruk replaced his great-uncle, who had preceded him in office, in the goddess's ledger. This suggests that the ledger contained up-to-date information about all the priests who were on duty for each of the 36 o days of the year.

The ledger in yos 7,167 is referred to as the lè $\hat{u}$ ša kizlaqu ša Bèltu-ša-Uruk. The meaning of the word kizlaqu is not understood, but it probably denotes the service duty of the priests, as suggested by San Nicolò. ${ }^{62}$ The same word is found in a similar context in a tablet from the Atkuppu archive of Borsippa, which records an agreement about the reedworker's service "aki kizlaqu ša Ezida" (вм 94615, c. reign of Cambyses). ${ }^{63}$

The entry of a priest's name in the ledger was the last step towards finalizing a prebend transfer. Up to that moment, the old owner not only remained responsible for the proper performance of the cultic tasks and for the payment of the various dues, levies and taxes resting on the prebend, but he also retained the right to enjoy the prebend's income, as can be seen in a phrase used in certain property deeds of the oxherd prebend:

mimma rēhānu u gu-ra-a $\left({ }^{64}\right)$ ša ekurru ša kutallu ša adi lā țuppi $\mathrm{PN}$ ikannakuma ana $\mathrm{PN}_{2}$ inamdinu ina muhhi isqu ilâ $\mathrm{PN}$ ultu ramnišu ana ekurru utțar

Whatever arrears and outstanding fees of the temple will arise on the prebend - dues dating from the time before $\mathrm{PN}$ signed over the property deed to $\mathrm{PN}_{2}$-PN must pay (these dues) himself (вм 26513: 18-23)

Iraq 64 (2002): 217-36 and Michael Jursa, "Accounting in Neo-Babylonian Institutional Archives: Structure, Usage, Implications," in Creating Economic Order: Record-keeping, Standardization, and the Development of Accounting in the Ancient Near East, ed. M. Hudson and C. Wunsch (Bethesda, MD: CDL, 2004), 170-178.

61 San Nicolò, "Parerga Babylonica XII," 194-195.

62 San Nicolò, "Parerga Babylonica XII," 195 n. 5. The translation suggested by CAD K, 477 "storeroom (of a temple)" cannot be correct in this context.

63 This tablet will be published by Kathleen Abraham in her forthcoming study of the Atkuppu archive. A third attestation (YOs 6, 235:3) refers to silver income (irbu) arising from the ki-za-la-a-qa of a deity.

64 See Caroline Waerzeggers and Michael Jursa, "On the Initiation of Babylonian Priests," Zeitschrift für Altorientalische und Biblische Rechtsgeschichte 14 (2008): 1-23 for this term, and for an edition of вм 26513 . 
TEBR 84 fits this context: it establishes the division of income between the previous and the new owner of a recently sold oxherd prebend: until the second month of Darius' I 25th year, the old owner would enjoy the outstanding income; afterwards, the new owner would carry off the pappasu (income) accruing to the prebend.

In Seleucid times, it was a right of the buyer to decide on which day he wanted to have his name added to the register and to accept all attendant rights and duties: 65

ūmu mala PN șebû isqāti šuāti ina lè̂̀ ša isqāti ša ina büt-ilāni ina šumišu ušallam

Any day that PN wishes, he may have (the registration of) this prebend fully (recorded) in his name on the wooden (registration) tablet for prebends which is in the temple (CAD B p. 28)

\subsection{Authority and Responsibility: the "Citizen" of the Rota}

There is no evidence in the Babylonian sources that the priestly courses were named after an ancestor or eponym and used as markers of time outside the temple, as in the case of the mishmarot. There are some indications, however, that the watches resorted under the authority of an individual who, in the fashion of a primus inter pares, was responsible for the performance of the watch's members, not only in cultic matters but also in civil ones. Therefore, the organizational principles of priestly labor did resonate further into society.

The clearest evidence for the leaders of priestly courses comes from Borsippa. ${ }^{66}$ At least five, but possibly as many as eight mār-banê bè $\bar{e}$-šapatti, "citizens, in charge of a fortnight," were employed by Ezida's bakers at any given time. These men were responsible for the continuity of the worship in the temple. If an interruption occurred in the service, the bél-šapatti was punishable. Apart from cultic performance, the bèl-šapatti oversaw the administrative obligations of the members of the watch, both within and outside the temple. Inside the temple, he collected the various levies and taxes that priests had to pay to the temple. Outside the temple, the bel-šapatti can be found in

65 Paola Corò, Prebende Templari in Età Seleucide, HANE/M 8 (Padova: S.a.r.g.o.n. Editrice e Libreria, 2005), 41-42; and see the texts edited by Corò on pages 154, 158, 16o-61, 163, 176, 180,187 for examples of the clause.

This section summarizes the discussion in Waerzeggers, Ezida, 209-12. 
charge of work gangs financed by priests who were liable to pay tax, or provide corvée, to the state.

It is not entirely understood how the bèl-šapatti was appointed. He probably assumed his role during a particular fortnight of the roster. This is suggested by vs 6, 284. The header of this text reads "Days (of) the šapattu of Kușurā/Kīnā" and is followed by a list of 15 days belonging to 10 different bakers, none of them Kuṣurā himself. Kuṣurā is mentioned with the title bēl-šapatti in another text (AchHist 15 no. 106) and he occurs in a list of failed flour offerings, caused by several negligent priests, as the person responsible or in charge of this group (AchHist 15 no. 109).

Kessler found evidence of a similar system in Uruk, where each day of service was associated both with a prebend-owner (who possessed the legal title) and a "lord of the day" (bēl-ümi) who was "die Person, die auf Grund eines ererbten Vorrechtes innerhalb einer spezifischen Berufsgruppe während des Dienstes in der manzaltu für den jeweiligen Zeitabschnitt die Verantwortung übernahm" (Kessler 1991: 93). These instances show that ancestral families retained responsibilities towards their prebendal patrimony, even after they had lost legal title of it.

\section{9}

\section{Conclusion}

Despite broad similarities between rotational temple service in Judaea and Babylonia, it remains difficult to compare the operation of priestly watches in these two contexts because the sources reveal such fundamentally different dimensions of these institutions. Biblical and extra-biblical evidence is concerned with the technical organization of the rotas, their historical and mythical origins, and the enduring stability of ancestral rights to temple service. The authors of these texts were primarily interested in the ideal of the rota - in the system as it was intended to work, harmoniously and unaffected by the passage of time. The Babylonian evidence, by contrast, shows us how the rotas worked in practice-with all the adaptations and contestations that occurred along the way. Because we are dealing mostly with legal texts, the rights of the individual priest are better documented than those of the family. Nevertheless, we have seen that clans, and in particular father's houses, loom large. The father's house comes into view only in emergency situations: for instance, when a member died without progeny, leaving his service slot empty, or when a member sold his share to a stranger without the consent of his paternal group. We do not know how (or even, if) membership to a particular priestly 
division was of interest to wider society; we certainly do not find evidence of individuals referring to such membership at any other occasion than within the context of temple service as such. Also, we remain uninformed about stories of origin that might have been told about the inception of priestly office in general and rotational office in particular. Perhaps the Babylonian Epic of Creation (Enūma Eliš) provides the fabric of such stories: the creation of time by Marduk, his installment of the 36o-day calendar, his assignment by lot of duties to the Anunnaki, and the work's exegesis of some of Marduk's fifty names all fit in the prebendary sphere. ${ }^{67}$

When looking at the Babylonian evidence, one could become dazzled by the sometimes tiny fractions of temple service. The fact that one person could be responsible for as little as half a day of service, a quarter of a day or even a smaller fraction, has often been seen by modern scholars as a sign of degeneration and systemic corruption in Babylonian temples. I should like to point out that post-biblical evidence shows a very similar picture: rabbinic sources suggest that in Jerusalem too, the actual temple service was much more fractured than the ideal of the 24 weekly courses suggest. In y. Ta'anit 68a, shares as small as half a day are assigned to entire father houses, something that from a Babylonian point of view seems completely reasonable. Surprisingly enough, such details about Jerusalem's priesthood appear in stories long after the temple was destroyed and the rotas had ceased to turn. Such disjunctions in the available testimony make comparisons challenging, but I hope nevertheless that the Babylonian materials can provide some opportunity for contextualizing Jewish temples in new ways.

67 Among Marduk's fifty ceremonial names, two refer to his interactions with temples and priests: the ninth name Asaralimnunna is explained as "he who is their provider, who assigns their prebends, whose tiara increases abundance for the land," the 33rd name Zulum is explained as "grantor of prebends and food offerings, tender of sanctuaries" (Benjamin R. Foster, Before the Muses: An Anthology of Akkadian Literature, $3 \mathrm{~d}$ ed. [Bethesda, MD: CDL, 2005], 476, 480). For Marduk's creation of time in Enūma Eliš, see Eleanor Robson, "Scholarly Conceptions and Quantifications of Time in Assyria and Babylonia, c. 750-250 BCE." in Time and Temporality in the Ancient World, ed. R.M. Rosen (Philadelphia: University of Pennsylvania Museum of Archaeology and Anthropology, 2004), 45-9o. 


\section{Acknowledgements}

This article was written in the context of project Persia \& Babylonia (P682241), financed by the European Research Council under its Horizon 2020 framework (Consolidator Grant). I wish to express my gratitude to the organizers of the conference Contextualizing Jewish Temples: Opportunities and Challenges at Bar-Ilan University in May 2018 for their kind invitation and to the attendants of the conference for their feedback on a preliminary version of this paper. 